\title{
El Abogado y el Ordenamiento Juridico de la Economía
}

\author{
Por el Dr. JOSE ROSELL RIOS \\ Catedrático de Economía Política
}

La función del abogado en el ordenamiento jurídico de la economía es obvia y su importancia resulta manifiesta. Pero, ante todo, y sin pretensiones, debemos precisar el concepto esencial de la Economía.

La Economía Política es una ciencia primordialmente social y del concepto que de ella se tenga dependerá la actuación del hombre, y en nuestro caso del abogado, en el ordenamiento jurídico de la vida económica $\mathrm{y}$ en la solución de sus problemas.

Las ciencias sociales tienen un doble objeto: "servir de instrumento para interpretar la rełlidad" (teórico) y "servir de guía a la acción" (práctico) (1).

La Economía Política incide en un aspecto de lo social -el económico- que no puede desvincularse del complejo del que forma parte. "No existe en la realidad social una zona perfectamente delimitada, que se pueda denominar económiea, y que pueda como tal constituir objeto de la ciencia económica. La realidad, como se ha dicho, se nos presenta siempre en su totalidad y complejidad. El acto humono mismo es totalidad. La adecuación de medios limitados a fines tiene siempre reflejos éticos, políticos, jurídicos, etc. Por consiguiente, no existe un acto económico separado de un acto ético, político, jurídico, etc." (2)

"La Economía Política no es una teoría de los negocios, sino una teoría de la vida" (Spann). En efecto, si decimos que la Economía Política no es una teoría de los negocios es porque su objeto no es el de resolver el problema egoísta de hacer dinero a toda costa, sino el de la aplicación de nuestros conocimientos de esta ciencia en el campo social. Debemos reconocer la subordinación de la Economía con respecto de la Etica y en este sentido resulta una teoría de la vida, pues no puede desconocer los

(1) Franceso Vito.-Economía Política.

(2) Idem. 
valores superiores y la subordinación a los mismos de los que son inferiores.

Los valores económicos, en el recto sentido de la palabra, no pueden estar en oposición con las normas éticas. La explotación del trabajador, con una jornada excesiva de trabajo por ejemplo, no tiene carácter económico, aunque ella pueda producir grandes ganancias a un empresario.

De lo dicho, anteriormente, aparece la vinculación entre lo económico y lo jurídico. Economía y Derecho se relacionan estrechamente. El derecho civil, aparte de los tratados de Personas y Familia, rige relaciones patrimoniales o económicas. Qué no decir del derecho comercial, del derecho minero, etc., en los cuales todo gira alrededor de aspectos económicos de la vida social. En el derecho del trabajo es donde se evidencia en forma más notable el nexo entre el Derecho y la Economía Política o Economía Social.

No puede, pues, discutirse la función del abogado en el ordenamiento jurídico de la economía. Pero, para que el abogado pueda actuar aceztadamente en ese campo debe tener un claro concepto de lo que es la Economía Política y conocer esta ciencia por lo menos en sus grandes lineamientos.

En consecuencia, el abogado y el jurista, posesionados de conocimientos acerca de los problemas económico-sociales y mós aún de los prin. cipios fundamentales que hemos señalado, están llamados a desempeñar una notable función dentro del campo indicado. Como miembro de la clase dirigente el abogado debe señalar los lineamientos del ordenamiento jurídico de la economía.

Doctrinariamente, el abogado, y el jurista en general, deben desarrollar una labor de orientación con escritos y trabajos relacionados con lo económico-social. Deben orientar y dirigir rectamente la actividad económica cuando se les pida su consejo legal en la materia, sin olvidar jamás que lo económico es sólo un aspecto de lo social y que sus problemas no pueden ser resueltos acertadamente si se prescinde en su solución del complejo al que pertenecen.

Igual labor le toca al abogado en los litigios en los que se ventilan asuntos patrimoniales $\mathrm{Y}$ económico-sociales. EI abogado debe tener siempre en cuenta los valores éticos y jurídicos para la recta solución de los problemas que su profesión le plantea. En la asesoría legal de las empresas industriales no se puede olvidar esos principios, ni dejar de lado la Justicia Social.

Ya sea como consejero legal, o como abogado en los litigios, o como magistrado, o como legislador o como funcionario del Estado, Ia labor de los profesionales del Derecho es evidente en el aspecto económico y social y su responsabilidad enorme e ineludible. 